\title{
Iran's Capabilities in Health Tourism: Mud in Lake Urmia
}

\author{
Maryam Yaghoubi ${ }^{1}$, Ali Ghanjal ${ }^{1, *}$ \\ ${ }^{1}$ Health Management Research Center, Baqiyatallah University of Medical Sciences, Tehran, Iran
}

*Corresponding Author: Ali Ghanjal, Ph.D. in Health Services Management, Health Management Research Center, Baqiyatallah University of Medical Sciences, Tehran, Iran. Email: ghanjala@yahoo.com

Article History: Received: 30 Jul. 2015; Accepted: 31 Aug. 2015; Online Published: 26 Nov. 2015

Cite this article as: Yaghoubi M, Ghanjal A. Iran's capabilities in health tourism: Mud in Lake Urmia. Int J Travel Med Glob Health. 2015;3(4):187.

\section{Dear Editor}

One of the most important factors affecting the dynamics of an economy and the sustainable development of any country is tourism [1-3]. One of the types of tourism, is Curative Tourism. Another name of curative tourism is therapeutic tourism. This type of tourism is often used to treat some diseases such as skin diseases or recreation in natural therapeutic sources. In this type of tourism, natural resources (spa and mineral waters, salt lakes, sludge treatment, sand dunes, radioactive sand and herbal baths) are used [4]. Iran is a country which has a great diversity of climate and natural resources. In this letter we have introduced the Urmia Lake in Iran and also the therapeutic properties of water and Mud.

Lake Urmia is in the northwestern corner of Iran and is one of the largest permanent hypersaline lakes in the world and the largest lake in the Middle East [5, 6]. It extends as much as $140 \mathrm{~km}$ from north to south and is as wide as $85 \mathrm{~km}$ east to west during high water periods [7].

This lake is the sixth largest saltwater lake on earth with a surface area of approximately 5,200 $\mathrm{km}^{2}\left(2,000 \mathrm{mile}^{2}\right)$, $140 \mathrm{~km}(87 \mathrm{mi})$ length, $55 \mathrm{~km}(34 \mathrm{mi})$ width, and $16 \mathrm{~m}$ (52 ft.) depth [8]. The water of the Urmia Lake and its mud in particular with abundant mineral salts, especially chloride and sulfate (sulfur) and iron compounds and iodine and the right amount of salt and high heat absorption and multiple organic matter and an appropriate dose of radioactivity is considered to be one of the finest Lakes for medical treatments [9]. The water of this lake is extremely calming and causes peripheral vasodilatation [10].

It can be said that it eliminates joint swelling and is also a treatment for the lymphatism system, rickets and some 12. chronic rheumatism. The sludge of the Urmia Lake is black plastic and the chemical composition is the Chlorinated mud. Low amounts of silica and high levels of hydrogen sulfide compounds, organic and colloidal materials such as Ferric oxide and Aluminum in the mud , have been used for the treatment of motor disease especially rheumatism and arthritis locally [11].

\section{References}

1. Ayoubian A, Tourani S, Hashemi Dehaghi Z. Medical Tourism Attraction of Tehran Hospitals. Int J Travel Med Glob Health. 2013;1(2):95-8

2. Izadi M, Saadat SH, Hashemidehaghi Z, Ayoubian A. Health tourism in Iran; Identify obstacles for development of this industry. Int $\mathbf{J}$ Travel Med Glob Health. 2013;1(2):89-4.

3. Izadi M, Ayoobian A, Nasiri T, Joneidi N, Fazel M, Hoseinpourfard M. Situation of health tourism in Iran; opportunity or threat. J Mil Med. 2015;14(2):69-75

4. Jallad A. Environment and Curative Tourism (in Arabic, translated by the author).Alam Al Kutub, 1st edition, Cairo, Egypt, 2000.

5. Hassanzadeh E, Zarghami M, Hassanzadeh Y. Determining the Main Factors in Declining the Urmia Lake Level by Using System Dynamics Modeling. Water Resources Manag. 2011;26(1):129-45.

6. Karbassi A, Bidhendi G, Pejman A, Bidhendi M. Environmental impacts of desalination on the ecology of Lake Urmia. J Great Lakes Res. 2010;36(3):419-24.

7. Jalili S, Kirchner I, Livingstone D, Morid S. The influence of largescale atmospheric circulation weather types on variations in the water level of Lake Urmia, Iran. International Journal of Climatology. 2011

8. https://en.wikipedia.org/wiki/Lake_Urmia

9. Meshkini A, Meshkini S. The therapeutic properties of water and mud of Lake Urmia. Iran South Med J. 2001;4(0):72.

10. Arabshahi A, Aria Far M. Medical tourism, health tourism and treatment capabilities in Iran. Quarterly of Geographical Space Tourism. 2013;3(9):133-52.

11. Gafori MR, Mortazavi R, Saberi A. Review weather and mud of Lake Urmia. J Engineering College. 1993;44(0):33-46. 